\title{
Differences in the Incidence of Diarrhoea in Children Aged 6-24 Months Who Receive Exclusive and Non-Exclusive Breastfeeding
}

\author{
Christine Handayani Tampubolon ${ }^{1}$, Ronny ${ }^{2}$, Florentina Rahabeat ${ }^{3}$ \\ 1,2,3 Medical Faculty, Universitas Kristen Indonesia, Jakarta \\ Corresponding Author: Christine Handayani Tampubolon
}

\begin{abstract}
Diarrhoea is still a problem for public health in developing countries, especially in Indonesia. The incidence of diarrhoea primarily affects infants in the 6-24 months age group because the infants start to obtain non-milk supplementary food in this age group, consequently increasing the risk of getting infected due to the consumption of germ-contaminated food. Breast milk contains required antibodies, and breastfed infants tend to have a more stable immune system than formula-fed infants. Most infant formulas are made from cow's milk or soybean. Formula feeding is indicated for those unable to obtain breast milk, and infant formula is often used as supplementary milk for mothers who cannot provide adequate breast milk. This study is aimed to determine the differences in the incidence of diarrhoea between 6-24 months old infants with exclusive breastfeeding versus infants with nonexclusive breastfeeding in the same age range. The researcher is analytical research with a casecontrol design, involving 60 infants as the research sample. Data were analyzed by using SPSS with a Chi-square test. The research results show differences in the incidence of diarrhoea between 6-24 months old infants with exclusive breastfeeding versus infants with non-exclusive breastfeeding in the same age range.
\end{abstract}

Keywords: Diarrhea, 6-24 months age, Exclusive breast milk, Non-exclusive breast milk

\section{INTRODUCTION}

Diarrhoea is a problem for people in developing countries, especially in Indonesia. Mortality, morbidity and incidence rates tend to increase. Five provinces in Indonesia that have a high incidence of diarrhoea are Aceh (10.2\%), Papua (9.6\%), DKI Jakarta (8.9\%), South Sulawesi $(8.1 \%)$ and Banten $(8.0 \%)$ [1;2]. Diarrhoea is an endemic disease in Indonesia and is also a potential extraordinary disease which is often accompanied by death.

The distribution pattern of diarrhoea incidence is evenly distributed in all age groups, with an incidence of $3.5 \%$. It is seen from the characteristics of the population, the age group under five is the group with the highest incidence of diarrhoea, with the age group 6-12 months at $7.6 \%$ and followed by the age group 12-23 months at $5.5 \%$. Diarrhoea mainly occurs in the age group under two years because the age of children is susceptible, especially in the first years of life. The highest incidence of diarrhoea attacks the age group of 6-24 months; this happens because babies begin to receive additional food outside of breast milk where the risk of participation of germs in different food is high [3].

Unhealthy behaviour is hazardous for babies to get diarrhoea because the baby's digestion has not been able to digest food other than breast milk. The baby loses the opportunity to get immune substances that can only be obtained from breast milk, 
and there is a possibility that the food given to the baby is contaminated with bacteria because the tools used to prepare the baby giving food or drink to babies is not sterile. Hence, breast milk for babies is the perfect food. It is due to the presence of essential antibodies in colostrum and breast milk. Besides that, breast milk is always safe and clean, so germs are improbable to enter the baby's body [4].

Formula-fed babies are 14.2 times more likely to have diarrhoea than breastfed babies. This situation illustrates that the baby's digestive system can absorb all breast milk products. It can be because breast milk contains a high nutritional value, antibodies, leukocyte cells, enzymes, and others that protect infants against various infections. After all, breast milk contains antibodies so that breastfed children have a more stable immune system than breast milk. Formulafed children. It is because breast milk contains high antibody factors. It is indicated by the formation of immunoglobulin $\mathrm{A}$ in colostrum produced in the first days of birth. Immunoglobulin A (IgA) will play a role in coating the baby's digestive tract so that germs do not enter the digestive tract and protect the baby so that the immune system will work properly [5].

Formula milk is milk for babies that mostly come from cow's milk or soy. Formula feeding is indicated for infants who, for some reason, do not receive breast milk or as an addition if breast milk is not sufficient, 2011 WHO reaffirmed that no food or liquid other than breast milk is necessary to meet the nutritional needs of infants during the first six months of life. After six months, the baby should start receiving a variety of foods, while breastfeeding continues for up to two years. Breastfeeding will meet the baby's needs during the age of six months without complementary foods [6].

Based on the above background, the authors are interested in conducting a study to determine the difference in the incidence of diarrhoea in children aged 6-24 months who are exclusively and not exclusively breastfed. The formulation of the problem answered in this study is "Is there a difference in the incidence of diarrhoea in children aged 6-24 months who receive exclusive and non-exclusive breastfeeding? The study aimed to determine the difference in the incidence of diarrhoea in children aged 6-24 months who received exclusive and non-exclusive breastfeeding.

\section{LITERATURE REVIEW}

Diarrhoea is defecation in infants or children more than three times per day, accompanied by changes in the consistency of stools to liquid with or without mucus and blood. Babies who drink breast milk often defecate more than 3-4 times per day. This condition cannot be called diarrhoea but is still physiological or normal as long as the baby's weight increases typically. It is not classified as diarrhoea but is a temporary lactose intolerance due to incomplete digestive tract development. For exclusively breastfed infants, a practical definition of diarrhoea is an increase in the frequency of bowel movements or the consistency of being watery, which the mother thinks is abnormal or not as usual. Sometimes in a child defecate less than three times per day, but the consistency is liquid. This condition can be called diarrhoea $[7 ; 8]$.

The mode of transmission of diarrhoea is generally through the faecaloral route, namely through food or drink contaminated with enteropathogens, or direct hand contact with patients or items that have been contaminated with the patient's faeces or indirectly through flies (through $4 \mathrm{~F}=$ finger, flies, fluid), fields). Risk factors that can increase the transmission of enteropathogens include: not fully breastfeeding for the first 4-6 months of the baby's life, inadequate supply of clean water, water pollution by faeces, lack of hygiene facilities (MCK), poor environmental and personal hygiene, preparation of and unhygienic food storage and improper weaning. In addition, several factors in patients can increase the tendency 
to get diarrhoea, including poor nutrition, immunodeficiency, reduced gastric acidity, decreased intestinal motility, suffering from measles in the last four weeks and genetic factors [9].

Most episodes of diarrhoea occur in the first two years of life. The highest incidence occurred in the age group 6-11 months when complementary feeding was given. This pattern describes the combined effect of lowering maternal antibody levels, the infant's lack of active immunity, the introduction of food that may be contaminated with faecal bacteria and direct contact with human or animal faeces when the infant begins to crawl.

Most intestinal infections are asymptomatic, and the proportion of these asymptomatics increases after two years of age due to the formation of active immunity. Asymptomatic infection may last several days or weeks. The patient's stool contains infectious viruses, bacteria or protozoan cysts. People with asymptomatic infections play an important role in spreading many enteropathogens, especially when they are not aware of the infection, do not maintain hygiene and move from place to place [10].

Social and economic limitations will affect the density of the residential environment. The level of parental education affects healthy behaviour and lifestyle [11]. Currently, no less than 25 types of microorganisms that can cause diarrhoea in children and infants have been identified. The leading infectious causes of diarrhoea due to infection are noninflammatory and inflammatory.

Enteropathogens cause noninflammatory diarrhoea through enterotoxin production by bacteria, destruction of villous surface cells by viruses, attachment by parasites, attachment and/or translocation from bacteria. In contrast, inflammatory diarrhoea is usually caused by bacteria that invade the intestine directly or produce cytotoxins. Some of the causes of diarrhoea in humans include the following: a) Bacterial groups such as Aeromonas, Bacillus cereus, Campylobacter jejuni,
Clostridium per fringe, Vibrio cholera, Escherichia coli, Salmonella, Shigella, Staphylococcus aureus; b) Virus groups such as Rotavirus, Astrovirus, Calicivirus (Norovirus, Sapovirus), Enteric adenovirus, Coronavirus; and c) Parasite groups such as Balantidum coli, Giardia lamblia, Entamoeba histolytica, Blastocystis hormones, Cryptosporidium parvum, Isospora Belli, Strongyloides stercoralis, Trichuris trichura [12].

In developing countries, the primary pathogens that cause acute diarrhoea in children are Rotavirus, enterotoxigenic Escherichia coli, Shigella, Campylobacter jejuni, and Cryptosporidium. The occurrence of diarrhoea caused by viruses, namely viruses that cause diarrhoea in humans, selectively infect and destroy cells at the ends of the villus in the small intestine. The virus will infect the epithelial lining in the small intestine and attack the villus in the small intestine. It causes the absorption function of the small intestine to be disturbed, and the damaged intestinal epithelial cells are replaced by new enterocytes, immature cuboidal in shape so that their function is not yet good. The villus atrophies and cannot absorb fluids and food correctly. Furthermore, fluids and food that are not absorbed or digested will increase intestinal colloid osmotic pressure, and intestinal hyperperistalsis occurs so that fluid and unabsorbed food are pushed out of the intestine through the anus, causing osmotic diarrhoea from incomplete absorption of water and nutrients [13].

In the small intestine, upper villus enterocytes are differentiated cells with digestive functions such as hydrolysis of disaccharides and absorption functions such as transport of water and electrolytes through co-transporters of glucose and amino acids. Crypto enterocytes are undifferentiated cells, which lack ciliated edge hydrophilic enzymes, which are secretors (secretors) of water and electrolytes. Thus selective viral infection of intestinal villus tip cells causes. Bacterial diarrhoea occurs through one of the 
mechanisms related to the regulation of ion transport in intestinal cells cAMP and cGMP. The pathogenesis of diarrhoea by Salmonella, Shigella, E. coli is somewhat different from the pathogenesis of diarrhoea by viruses, but the principle is almost the same. The difference is that these bacteria can penetrate (invasion) the mucosal cells of the small intestine to cause a systemic reaction. Shigella toxin can also enter the nerve fibres of the brain, causing seizures. Diarrhoea by these two bacteria can cause blood in the stool called dysentery [14].

$$
\text { Intestinal infections cause }
$$
gastrointestinal signs and symptoms and other symptoms when extra-intestinal complications occur, including neurologic manifestations. Gastrointestinal symptoms may include diarrhoea, abdominal cramps, and vomiting, whereas systemic manifestations vary depending on the cause. Patients with watery diarrhoea pass stools that contain large amounts of sodium, chloride, and bicarbonate ions. This loss of water and electrolytes increases with vomiting, and water loss also increases when there is heat. It can lead to dehydration, metabolic acidosis, and hypokalemia. Dehydration is the most dangerous condition because it can cause hypovolemia, cardiovascular collapse and death if not treated properly.

If there is heat, it is possible because of the inflammatory process or due to dehydration. Body heat is typical in patients with inflammatory diarrhoea. More severe abdominal pain and tenesmus in the lower abdomen and rectum suggest colonic involvement [15]. Mother's Milk (ASI) is a liquid milk secretion from the breast after birth. Mother's Milk (ASI) contains ideal nutrients to support babies' optimal health, growth, and development. Mother's Milk (ASI) contains fat, carbohydrates, protein, micronutrients and antibodies in the right amount for digestion, brain development and baby growth, prevents various diseases, is safe and guaranteed cleanliness because it is directly given to babies avoid digestive disorders.
International guidelines advocating exclusive breastfeeding for the first six months are based on scientific evidence about the benefits of breastfeeding for infants' survival, growth and development. Breast milk (ASI) provides all the energy and nutrients with a baby needs for the first six months of life. Exclusive breastfeeding reduces infant mortality rates caused by various diseases that commonly afflict babies, such as diarrhoea and pneumonia and accelerates recovery when sick. Exclusive breastfeeding (ASI) provides only breast milk without providing additional food and drinks to infants from birth to 6 months of age, except for drugs and vitamins $[4 ; 7]$.

Stage I breast milk is colostrum, the first fluid secreted by the breast glands from the first day to the third or fourth day. Colostrum is yellowish due to the high composition of fat and living cells. Colostrum is an excellent laxative (intestinal cleanser) for cleaning the meconium so that the intestinal mucosa of a newborn baby is immediately clean and ready to receive breast milk. It causes the baby to defecate often, and the stool is black. Colostrum contains more protein than mature breast milk, but in contrast, to mature breast milk is colostrum, the main protein is globulin (gamma globulin) which contains more antibodies than mature breast milk, which can provide protection for babies up to 6 months of age. The total energy is lower when compared to mature breast milk, only $58 \mathrm{Cal} / 100 \mathrm{ml}$ of colostrum. Fat-soluble vitamins are higher when compared to mature breast milk, while water-soluble vitamins can be higher or lower. The lipid colostrum contains a lot of cholesterol and lecithin compared to mature milk. The $\mathrm{pH}$ in colostrum is more alkaline than mature breast milk, and there are trypsin inhibitors, so the hydrolysis of proteins in the baby's intestines is less than perfect. It increases antibody levels in infants, and in colostrum, the volume ranges from $150-300 \mathrm{ml} / 24$ hours [16]. 
Stage II breast milk is the transitional milk from colostrum to mature breast milk, secreted from day 4 to day 10 of lactation. The volume of breast milk increases, but the protein content is lower, while the carbohydrate and fat content is higher. It is to meet the baby's needs because the baby's activities are starting to be active, and the baby has started to adapt to the environment so that the milk production starts to stabilize [17].

Stage III breast milk is mature breast milk, which is breast milk that is secreted from the 10th day onwards. The composition is relatively constant, and it is a yellowish-white liquid caused by the colour of Ca-caseinate salt, riboflavin and carotene contained in it there are antimicrobial factors, namely: antibodies against bacteria and viruses, cells (granulocyte phagocytes and macrophages and T-type lymphocytes), enzymes (lysozyme, lactoperoxidase, lipase, catalase, phosphatase, amylase, phosphodiesterase, alkaline phosphatase), proteins (lactoferrin, B12 binding protein), resistance factors against staphylococci, and characteristic biochemical properties, low buffer capacity and presence of Bifidus factor [7].

Lactoferrin is an iron-binding protein that is strong bacteriostatic against Escherichia coli and inhibits Candida albicans.7 Lactobacillus Bifidus is a bacterial colony that metabolizes lactose into lactic acid, which causes a low $\mathrm{pH}$ so that the growth of pathogenic bacteria will be inhibited. Immunoglobulin provides an effective defence mechanism against bacteria and viruses (especially $\operatorname{IgA}$ ) and, when combined with complement and lysozyme, is a direct antibacterial against E.Coli. This lysozyme factor and complement is a non-specific antibacterial that regulates the growth of intestinal flora. Leukocyte factor and $\mathrm{pH}$ of breast milk prevent the growth of pathogenic bacteria [18]. The composition of breast milk is carbohydrates, fats, proteins, minerals, water, protective substances.
Formula Milk: Formula milk is milk made from cow's milk or artificial milk whose composition has been modified to be used as a substitute for breast milk. Formula milk has been modified to approximate the nutritional content of breast milk. However, this milk is still not an appropriate substitute because breast milk is higher in cholesterol and saturated fatty acids than formula milk.

The formula for term infants can be classified into two parts: a) First Formula (starter formula)-A formula based on cow's milk protein used from birth to 12 months of age. This formula is also made from soy and goat's milk protein [8; 10]; and b) Follow-on formula for infants aged six months and over. There is no need to replace the first formula with a follow-up formula for babies with good intake and have started to be given solid food, but the choice still falls to the parents. The difference between these two types of formula is not protein content but usually lies in mineral content such as iron and calcium $[8 ; 10]$. The composition of formula milk is protein, fat, carbohydrates, vitamins, minerals, and trace elements.

\section{RESEARCH METHOD}

This study is an analytic survey with a case-control design using a retrospective approach. The place of this research was carried out at Posyandu Cendana, RW 11, Caawang Village. Research Time: This research started from September to December 2017. The population of this research target was mothers who have children aged 6-24 months who visited Posyandu Cendana, RW 11, Kelurahan Cawang. In contrast, the sample of this study was children aged 6-24 months who received exclusive and non-exclusive breastfeeding according to the inclusion criteria and were willing to be respondents in this study. Sampling in this study using purposive sampling. The instrument used in this study was a questionnaire (Adopted from Lailatus Sa'Diyah, 2014). The researcher then modified the questionnaire according to the research needs to be carried 
out, and the validity of the questionnaire was tested using the SPSS program. Data were analyzed through the stages of coding, editing, entry and cleaning. The data that has been collected is then processed and analyzed using univariate and bivariate analysis.

\section{RESULT AND DISCUSSION}

Table 1. Characteristics of research subjects

\begin{tabular}{|l|l|l|}
\hline Variable & N & \% \\
\hline Age & & \\
\hline 6-12 Months & 44 & 73,3 \\
\hline$>12-24$ Months & 16 & 26,7 \\
\hline Gender & & \\
\hline Male & 17 & 28,3 \\
\hline Female & 43 & 71,7 \\
\hline Mother Education & & \\
\hline Senior High School & 19 & 31,7 \\
\hline Junior High School & 41 & 68,3 \\
\hline
\end{tabular}

Based on table 1, most of the research subjects were aged 6-12 months, namely 44 people $(73.3 \%)$. Most of the research subjects were female, as many as 43 people $(71.7 \%)$ with a mother's education level of senior high school and 41 people $(68.3 \%)$.

Table 2. The incidence of diarrhoea in Asian children 6-12 months and >12-24 months

\begin{tabular}{|l|l|l|l|l|l|l|l|}
\hline \multirow{3}{*}{ Age } & \multicolumn{3}{|l|}{ Diarrhoea } & \multicolumn{2}{l|}{ Total } & \multirow{2}{*}{$\begin{array}{l}\boldsymbol{p} \text { - } \\
\text { value }\end{array}$} \\
\cline { 2 - 7 } & \multicolumn{2}{|l|}{ Yes } & \multicolumn{2}{l|}{ No } & \multicolumn{2}{|l|}{} & \\
\cline { 2 - 7 } & $\mathrm{n}$ & $\%$ & $\mathrm{n}$ & $\%$ & & \\
\hline 6-12 Months & 31 & $70,5 \%$ & 13 & $29,5 \%$ & 44 & 0,004 \\
\hline $\begin{array}{l}>12-24 \\
\text { Months }\end{array}$ & 10 & $62,5 \%$ & 6 & $37,5 \%$ & 16 & \\
\hline Total & 41 & & 19 & & 60 & \\
\hline
\end{tabular}

Based on table 2, it was found that children aged 6-12 months who had diarrhoea were 31 people $(70.5 \%)$ and children aged >12-24 months who had diarrhoea were ten people $(62.5 \%)$, so the pvalue was 0.004 , which means that there is a significant relationship between the incidence of diarrhoea in children aged 6-12 months and >12-24 months.

Table 3. The incidence of diarrhoea in children aged 6-24 months by sex

\begin{tabular}{|l|l|l|l|l|l|l|}
\hline \multirow{4}{*}{ Gender } & \multicolumn{2}{|l|}{ Diarrhoea } & \multirow{2}{*}{ Total } & \multirow{2}{*}{ p-value } \\
\cline { 2 - 5 } & \multicolumn{2}{|l|}{ Yes } & \multicolumn{2}{l|}{ No } & \\
\cline { 2 - 5 } & n & $\%$ & n & \% & & \\
\hline Male & 12 & $70,6 \%$ & 5 & $29,4 \%$ & 17 & 0,907 \\
\hline Female & 31 & $72,1 \%$ & 12 & $27,9 \%$ & 43 & \\
\hline Total & 43 & & 17 & & 60 & \\
\hline
\end{tabular}

Based on table 3 , it was found that 31 girls $(72.1 \%)$ had diarrhoea and 12 (70.6\%). Incidence of diarrhoea in children aged 6-24 months with gender.

Table 4. The incidence of diarrhoea in children aged 6-24 months who are exclusively and not exclusively breastfed

\begin{tabular}{|c|c|c|c|c|c|c|}
\hline \multirow[t]{3}{*}{ Breastfeeding } & \multicolumn{3}{|c|}{ Diarrhoea } & \multirow{2}{*}{\multicolumn{2}{|c|}{ Total }} & \multirow{2}{*}{$\begin{array}{l}p \text { - } \\
\text { value }\end{array}$} \\
\hline & \multicolumn{2}{|c|}{ Yes } & No & & & \\
\hline & $\mathbf{n}$ & $\%$ & $\mathrm{n}$ & $\%$ & & \\
\hline $\begin{array}{l}\text { Exclusive } \\
\text { breastfeeding }\end{array}$ & 12 & $40,0 \%$ & 18 & $60,0 \%$ & 30 & 0,002 \\
\hline $\begin{array}{l}\text { Not Exclusive } \\
\text { Breastfeeding }\end{array}$ & 24 & $80,0 \%$ & 6 & $20,0 \%$ & 30 & \\
\hline Total & 36 & & 24 & & 60 & \\
\hline
\end{tabular}

Based on table 4 , it was found that children who were exclusively breastfed had diarrhoea as many as 12 people $(40.0 \%)$ and children who were not exclusively breastfed experienced diarrhoea as many as 24 people $(80.0 \%)$. So the p-value of 0.002 means there is a relationship. There is a significant difference between the incidence of diarrhoea with children aged 6-24 months who receive exclusive and non-exclusive breastfeeding.

Table 5. The incidence of diarrhoea in children aged 6-24 months with mother's level of knowledge

\begin{tabular}{|l|l|l|l|l|l|l|}
\hline \multirow{2}{*}{$\begin{array}{l}\text { Mother's } \\
\text { Knowledge }\end{array}$} & \multicolumn{3}{|l|}{ Diarrhoea } & \multirow{2}{*}{ Total } & \multirow{2}{*}{$\begin{array}{l}\boldsymbol{p} \text { - } \\
\text { vevel }\end{array}$} & \multicolumn{2}{|l|}{ Yes } & \multicolumn{1}{l|}{ No } & & \\
\cline { 2 - 6 } & n & \% & n & \% & & \\
\hline Good & 16 & $43,2 \%$ & 21 & $56,8 \%$ & 37 & 0,001 \\
\hline Poor & 20 & $87,0 \%$ & 3 & $13,0 \%$ & 23 & \\
\hline Total & 36 & & 24 & & 60 & \\
\hline
\end{tabular}

Based on table 5, it was found that mothers with a low level of knowledge and the incidence of diarrhoea in children aged 6-24 months were 20 people $(87.0 \%)$ while mothers with a good level of knowledge and the incidence of diarrhoea in children aged 6-24 months were 16 people (43.2\%). Then the p-value of 0.001 means a significant relationship between the incidence of diarrhoea in children aged 6-24 months with the mother's level of knowledge.

Table 6. The incidence of diarrhoea in children aged 6-24 months with maternal education level

\begin{tabular}{|l|l|l|l|l|l|l|}
\hline \multirow{2}{*}{$\begin{array}{l}\text { Mother's } \\
\text { Knowledge } \\
\text { Level }\end{array}$} & \multicolumn{3}{|l|}{ Diarrhoea } & \multirow{2}{*}{ Total } & \multicolumn{1}{l|}{$\begin{array}{l}\text { - } \\
\text { value }\end{array}$} \\
\cline { 2 - 6 } & \multicolumn{2}{|l|}{ Yes } & \multicolumn{2}{l|}{ No } & \\
\cline { 2 - 6 } & n & $\%$ & $\mathbf{n}$ & $\%$ & & \\
\hline $\begin{array}{l}\text { Junior High } \\
\text { School }\end{array}$ & 22 & $75,9 \%$ & 7 & $24,1 \%$ & 29 & 0,004 \\
\hline $\begin{array}{l}\text { Senior High } \\
\text { School }\end{array}$ & 12 & $38,7 \%$ & 19 & $61,3 \%$ & 31 & \\
\hline Total & 34 & & 26 & & 60 & \\
\hline
\end{tabular}


Based on table 6, it was found that mothers with a junior high school education level and the incidence of diarrhoea in children aged 6-24 months were 22 people (75.9\%) while mothers with a high school education level and the incidence of diarrhoea in children aged 6-24 months were 12 people $(38,7 \%)$. Then the $\mathrm{p}$-value is 0.004 , which means there is a significant relationship between the incidence of diarrhoea in children aged 6-24 months and the mother's education level.

This study found that most cases of diarrhoea occurred in children aged 6-12 months. It is the same as research conducted by Rahmadani, who found that $54.25 \%$ of children aged 6-12 months had diarrhoea and $46.75 \%$ of children aged $>12-24$ months, and research conducted by Eptika found that the incidence of diarrhoea significantly affects age. Children [19;20] This is also following the theory that most episodes of diarrhoea occur in the first two years of life. The highest incidence occurred in 6-12 months when complementary feeding was given.

This study found that the incidence of diarrhoea is most common in girls. It is different from the research conducted by Dahliansyah, which found more cases of diarrhoea in boys because boys are more active and have direct contact with foreign objects that may be contaminated with germs and bacteria that can cause diarrhoea. Most of the children were male, namely 72 children $(66.7 \%)$ because boys played more often and were quickly exposed to agents caused by diarrhoea [21]. However, gender has not been entirely a factor in the incidence of diarrhoea [22].

This study found differences in the incidence of diarrhoea in children who were exclusively and not exclusively breastfed. It follows the theory that children who are exclusively breastfed automatically get antiinfective immunity. There were differences in the incidence of diarrhoea in children who were exclusively breastfed, not exclusively breastfed [23]. This study found that the incidence of diarrhoea based on the mother's level of knowledge mainly was less knowledgeable. The problem of lack of knowledge of mothers with the incidence of diarrhoea can be caused by lack of information on mothers causing not to attach importance to a healthy lifestyle [24]. In The relationship between knowledge and a mother's attitude plays an essential role in the incidence of diarrhoea [25].

This study found that the incidence of diarrhoea was based on the mother's education level. The results showed that most of them had junior high school education. The level of a mother's education is very influential on the incidence of diarrhoea. Mothers with a good education will know more about children's health than mothers with low levels of education [26]. However, the incidence of diarrhoea is not only influenced by education but also social and economic factors that are very influential in the incidence of diarrhoea.

\section{CONCLUSION}

Based on the results of the research and discussion, the conclusions from the research results can be explained as follows: a) The highest percentage of respondents aged 6-12 months is 44 people (71.0\%), with female sex as many as 43 people $(69.4 \%)$; b) There is a significant difference between the incidence of diarrhoea in infants aged 6-12 months and aged $>12-24$, the value $(\mathrm{p}=0.004)$; $\mathrm{c})$ There is no difference between the incidence of diarrhoea in infants aged 6-24 months based on gender, value $(\mathrm{p}=0.969)$; $)$ There was a significant difference between the incidence of diarrhoea in infants aged 6-24 months who received exclusive and non-exclusive breastfeeding, with a value of $(\mathrm{p}=0.002)$; $\mathrm{e})$ There is a significant difference between the incidence of diarrhoea and the mother's level of knowledge, value ( $\mathrm{p}=0.001)$; and $\mathrm{f}$ ) There is a significant difference between the incidence of diarrhoea with the mother's education level, the value $(\mathrm{p}=0.004)$.

\section{Acknowledgement: None}




\section{Conflict of Interest: None}

\section{Source of Funding: None}

\section{Ethical Approval: Approved}

\section{REFERENCES}

1. Tosepu, R., Merdeka, E. K. P., \& Jumakil, J. (2019, September). The Epidemiological and Spatial of Diarrhea in Konawe Utara District, Indonesia. In ICEASD\&ICCOSED 2019: International Conference on Environmental Awareness for Sustainable Development in conjunction with International Conference on Challenge and Opportunities Sustainable Environmental Development, ICEASD \& ICCOSED 2019, 1-2 April 2019, Kendari, Indonesia (p. 204). European Alliance for Innovation.

2. Tungga, Tersia Marentiva, Yulia Lanti Retno Dewi, and Bhisma Murti. "Path analysis: psychososial and economic factors affecting diarrhea incidence in children under five in Jayapura, Papua." Journal of Epidemiology and Public Health 3, no. 03 (2018): 331-341.

3. Gebreegziabher, Tafere, Nigatu Regassa, Micaela Wakefield, Kelly Pritchett, and Susan Hawk. "Disparities in the prevalence and risk factors of anaemia among children aged 6-24 months and 25-59 months in Ethiopia." Journal of Nutritional Science 9 (2020).

4. Carroll, Katherine. "Body dirt or liquid gold? How the 'safety' of donated breastmilk is constructed for use in neonatal intensive care." Social Studies of Science. 44, no. 3 (2014): 466-485.

5. Woof, Jenny M., and Michael A. Kerr. "The function of immunoglobulin A in immunity." The Journal of Pathology: A Journal of the Pathological Society of Great Britain and Ireland 208, no. 2 (2006): 270282.

6. Muchina, E. N., and P. M. Waithaka. "Relationship between breastfeeding practices and nutritional status of children aged 0-24 months in Nairobi, Kenya." African Journal of Food, Agriculture, Nutrition and Development 10, no. 4 (2010).

7. Baldi, Fabio, Maria Antonia Bianco, Gerardo Nardone, Alberto Pilotto, and Emanuela Zamparo. "Focus on acute diarrhoeal disease." World journal of gastroenterology: $W J G 15$, no. 27 (2009): 3341.

8. Issenman, Robert M., Robert Bruce Filmer, and Peter A. Gorski. "A review of bowel and bladder control development in children: how gastrointestinal and urologic conditions relate to problems in toilet training." Pediatrics 103, no. Supplement 3 (1999): 1346-1352.

9. Pusceddu, Sara, Roberta Elisa Rossi, Martina Torchio, Natalie Prinzi, Monica Niger, Jorgelina Coppa, Luca Giacomelli et al. "Differential diagnosis and management of diarrhea in patients with neuroendocrine tumors." Journal of Clinical Medicine 9, no. 8 (2020): 2468.

10. Gao, Zhiru, Yinghui $\mathrm{Xu}$, Chao Sun, $\mathrm{Xu}$ Wang, Ye Guo, Shi Qiu, and Kewei Ma. "A systematic review of asymptomatic infections with COVID-19." Journal of Microbiology, Immunology and Infection. 54, no. 1 (2021): 12-16.

11. Miguel-Berges, María L., Konstantina Zachari, Alba M. Santaliestra-Pasias, Theodora Mouratidou, Odysseas Androutsos, Violeta Iotova, Sonya Galcheva et al. "Clustering of energy balance-related behaviours and parental education in European preschool children: the ToyBox study." British Journal of Nutrition 118, no. 12 (2017): 1089-1096.

12. Guttman, Julian A., Fereshte N. Samji, Yuling Li, Wanyin Deng, Ann Lin, and B. Brett Finlay. "Aquaporins contribute to diarrhoea caused by attaching and effacing bacterial pathogens." Cellular microbiology. 9, no. 1 (2007): 131-141.

13. Camilleri, Michael, and Joseph A. Murray. "Diarrhea and constipation." Harrisons Principles of Internal Medicine. Fauci, AS ed., McGraw Hill Medical, New York (2008): 245-255.

14. DuPont, Herbert L. "Bacterial diarrhea." New England Journal of Medicine 361, no. 16 (2009): 1560-1569.

15. Bernstein, Charles N., Michael Fried, J. H. Krabshuis, Henry Cohen, R. Eliakim, Suleiman Fedail, Richard Gearry et al. "World Gastroenterology Organization Practice Guidelines for the diagnosis and management of IBD in 2010." Inflammatory bowel diseases 16, no. 1 (2010): 112-124.

16. Jones, C. M., R. E. James, J. D. Quigley III, and M. L. McGilliard. "Influence of pooled colostrum or colostrum replacement on IgG 
and evaluation of animal plasma in milk replacer." Journal of dairy science 87, no. 6 (2004): 1806-1814.

17. Bergman, Jill, and Nils Bergman. "Whose choice? Advocating birthing practices according to baby's biological needs." The Journal of Perinatal Education 22, no. 1 (2013): 8-13.

18. Wagner, Carol L., Sarah N. Taylor, and Donna Johnson. "Host factors in amniotic fluid and breast milk that contribute to gut maturation." Clinical reviews in allergy \& immunology 34, no. 2 (2008): 191-204.

19. Rahmadhani, Eka Putri, Gustina Lubis, and Edison Edison. "Hubungan pemberian ASI eksklusif dengan angka kejadian diare akut pada bayi usia 0-1 tahun di Puskesmas Kuranji Kota Padang." Jurnal Kesehatan Andalas 2, no. 2 (2013): 62-66.

20. Eptika, Indah, Djayusmantoko Djayusmantoko, and Merita Merita. "Hubungan Prilaku Pemberian MP-ASI dan Kejadian Diare dengan Status Gizi Bayi Usia 6-11 Bulan Di Puskesmas Simpang Kawat Kota Jambi." Jurnal Akademika Baiturrahim Jambi 8, no. 2 (2019): 252260.

21. Dahliansyah, Dahliansyah, Diffah Hanim, and Harsono Salimo. "Hubungan Pemberian ASI Eksklusif, Status Gizi, dan Kejadian Diare dengan Perkembangan Motorik pada 1000 Hari Pertama Kehidupan." Sari Pediatri 20, no. 2 (2018): 70-8.

22. Darkom, Raabi. "Investigation of common bacteria isolates in malnourished children five (5) years and below admitted in Tamale
Teaching Hospital in the Northern Region of Ghana." PhD diss., 2015.

23. Lamberti, Laura M., Christa L. Fischer Walker, Adi Noiman, Cesar Victora, and Robert E. Black. "Breastfeeding and the risk for diarrhea morbidity and mortality." BMC public health 11, no. 3 (2011): 1-12.

24. Nguyen, Trung Vu, Phung Le Van, Chinh Le Huy, Khanh Nguyen Gia, and Andrej Weintraub. "Etiology and epidemiology of diarrhea in children in Hanoi, Vietnam." International Journal of Infectious Diseases 10, no. 4 (2006): 298-308.

25. Workie, Hailemariam Mekonnen, Abdilahi Sharifnur Sharifabdilahi, and Esubalew Muchie Addis. "Mothers' knowledge, attitude and practice towards the prevention and home-based management of diarrheal disease among under-five children in Diredawa, Eastern Ethiopia, 2016: a crosssectional study." BMC pediatrics 18 , no. 1 (2018): 1-9.

26. Oli, Natalia, Abhinav Vaidya, Madhusudan Subedi, Gabriele Eiben, and Alexandra Krettek. "Diet and physical activity for children's health: a qualitative study of Nepalese mothers' perceptions." BMJ open 5, no. 9 (2015): e008197.

How to cite this article: Tampubolon $\mathrm{CH}$, Ronny, Rahabeat F. Differences in the incidence of diarrhoea in children aged 6-24 months who receive exclusive and non-exclusive breastfeeding. Int J Health Sci Res. 2021; 11(10): 378-386. DOI: https://doi.org/10. 52403/ijhsr.20211048 